\title{
Interleukin-6 inhibits voltage-gated sodium channel activity of cultured rat spinal cord neurons
}

Li X, Chen W, Sheng J, Cao D, Wang W. Interleukin-6 inhibits voltagegated sodium channel activity of cultured rat spinal cord neurons.

Objective: Interleukin-6 (IL-6) is a pleiotropic proinflammatory cytokine that plays a key role in the injuries and diseases of the central nervous system (CNS). A voltage-gated $\mathrm{Na}^{+}$channel (VGSC) is essential for the excitability and electrical properties of the neurons. However, there is still limited information on the role of IL-6 in voltage-gated sodium channels. Our study aimed to investigate the effects of IL- 6 on $\mathrm{Na}^{+}$currents in cultured spinal-cord neurons. Methods: VGSC currents were activated and recorded using whole-cell patch-clamp technique in the cultured rat spinal cord neurons. The effects of IL-6 concentration and exposure duration were examined. To determine whether any change in the number of channels in the plasma membrane can inhibit IL- 6 on VGSC currents, we examined the expression of $\alpha_{1 \mathrm{~A}}(\mathrm{SCN} 1 \alpha)$ subunit mRNA level and protein level in the neurons before and after IL-6 induction using real-time polymerase chain reaction.

Results: We verified that IL-6, through a receptor-mediated mechanism, suppressed $\mathrm{Na}^{+}$currents in a time- and dose-dependent manner, but did not alter the voltage-dependent activation and inactivation. Gp130 was involved in this inhibition. Furthermore, the spike amplitude was also inhibited by IL- 6 in the doses that decreased the $\mathrm{Na}^{+}$currents.

Conclusion: VGSC currents are significantly inhibited by IL-6. Our findings reveal that the potential neuroprotection of IL-6 may result from the inhibitory effects on VGSC currents.

\section{Xiaoning $\mathrm{Li}^{1,2}$, Weiqiang Chen², Jiangtao Sheng', Deliang $\mathrm{CaO}^{2}$, Wanchun Wang ${ }^{1}$}

'Department of Orthopaedics, The Second Xiangya Hospital of Central South University, Hunan, China; and ${ }^{2}$ Department of Medical Microbiology, Immunology \& Cell Biology, Simmons Cancer Institute, Southern Illinois University School of Medicine, Springfield, USA

Keywords: Interleukin-6; patch-clamp recording; spinal cord neurons; voltage-gated sodium channels

Wanchun Wang, Department of Orthopaedics, The Second Xiangya Hospital of Central South University, Middle Ren-Min Road No. 139, Changsha, Hunan 410011, People's Republic China.

Tel: +86 7318529 5128;

Fax: +86 73185295128 ;

E-mail: wcwang2013@yeah.net

Accepted for publication August 31, 2013

First published online October 8, 2013

\section{Introduction}

Interleukin-6 (IL-6), a member of the pleiotropic cytokine family, has complex effects on the central nervous system (CNS) (1). Under normal conditions, the production of IL- 6 in the CNS is highly regulated $(2,3)$. In neural functional disorders, such as spinal cord diseases and injuries, IL-6 expression increases remarkably $(4,5)$. The increased IL- 6 may reflect a harmful process as an injurious mediator and a negative effect on neuroprotection. For example, IL-6 is a detrimental player contributing to the pathogenesis of many spinal cord diseases, for example, cervical spondylotic myelopathy and spinal cord injury (6-8). However, the increase of IL-6 may also represent a compensative mechanism for neural repair. For instance, IL-6 regulates neuronal function and development in the innate response of the CNS to injuries and diseases
$(9,10)$, and exerts neurotropic and neuroprotective effects on glutamate- and $N$-methyl-D-aspartic acid (NMDA)-induced neuronal damage (11-14). These controversial functions of IL-6 in the CNS suggest the need for an extensive investigation of its role in spinal cord physiology and pathology.

Voltage-gated sodium channels, which are dynamic transmembrane proteins consisting of a pore-forming $\alpha$-subunit $(220-260 \mathrm{kDa})$ and auxiliary $\beta$-subunits $(32-36 \mathrm{kDa})$, mediate the inward sodium currents of excitable cells and are thus key regulators of action potential (AP) generation and propagation (15-17). It has been reported that in the fibroblast growth factor homologous factors knockout mice, the electrophysiology properties of voltage-gated sodium channels are changed, resulting in the cerebellar granule neurons incapable of being induced to repetitively fire AP (18). In addition, 
a mutation of the $\mathrm{Na}_{\mathrm{V}} 1.7$ channel alters the excitability in different types of neurons (19). In the sensory neurons of the PNS, the $\mathrm{Na}^{+}$channels contribute to inflammatory and neuropathic pain (20), and serve as analgesic drug targets (21).

Despite the evidence that both IL-6 and voltagegated sodium channels are involved in neuronal pathogenesis and protection, there is still limited information on the role of IL-6 in voltage-gated sodium channels. In the present study, we focused for the first time on voltage-gated sodium channels to indicate the mechanism of the neuroprotective effect of IL-6 on voltage-gated sodium channels by means of whole-cell patch-clamp methods and real-time polymerase chain reaction (PCR).

\section{Materials and methods}

Spinal cord neuron culture

The primary culture of rat spinal cord neurons was performed according to the previous reports $(21,22)$. The animals used in this study were housed and treated according to the guidelines for care and use of experimental animals of the Ethics Committee of Xiangya University Medical College. Primary cultures of spinal cord neurons were prepared from embryonic day 14 (E14) foetal rats. SpragueDawley rats were purchased from Central South University Xiangya Medical College Experimental Animal Centre, Changsha, China. All procedures were measured up to the national standard. Briefly, the spinal cord cleaned of its meningeal membranes was trypsinised for 2 min with $4 \mathrm{ml}$ of $0.25 \%$ trypsin (Invitrogen, NY, USA) at $37^{\circ} \mathrm{C}$, and interrupted with a $0.5 \mathrm{ml}$ foetal bovine serum (FBS, HyClone). The cells were collected by centrifugation for $10 \mathrm{~min}$ at $900 \times \mathrm{g}$. The pellet was resuspended by minimum essential medium (MEM, Invitrogen). $1 \times 10^{6}$ cells were plated onto a $22 \times 22 \mathrm{~mm}$ glass cover slip that was pretreated with $12.5 \mu \mathrm{g} / \mathrm{ml}$ Poly-D-Lysine (Sigma; in water). $2 \mathrm{mM}$ glutamine (Sigma), 1\% B-27 supplement and $10 \%$ FBS were added into the MEM immediately before use. The $35 \mathrm{~mm}$ dishes were incubated at $37^{\circ} \mathrm{C}, 5 \% \mathrm{CO}_{2} / 95 \%$ air with $2 \mathrm{ml}$ culture medium. Half of the culture medium was changed every 3 days. All experiments were conducted at days 6-12 in vitro.

A different dose of IL-6 (Sigma) was applied to the medium for $24 \mathrm{~h}$, or $10 \mathrm{ng} / \mathrm{ml}$ of IL-6 was applied for 4, 8, 24 or $48 \mathrm{~h}$. For pharmacological experiments, IL-6 receptor antibody $(1 \mu \mathrm{g} / \mathrm{ml}$; Sigma) and/or antigp130 antibody ( $1 \mu \mathrm{M}$; Sigma) were applied to medium at $30 \mathrm{~min}$ before IL-6 $(10 \mathrm{ng} / \mathrm{ml})$ and then the cultures was co-treated for $24 \mathrm{~h}$.
Electrophysiological recording

Electrophysiological recording of the rat spinal cord neurons was carried out according to the previous reports (17). For the whole-cell recording of the voltage-gated $\mathrm{Na}^{+}$currents, the bath solution had the following composition (in $\mathrm{mM}$ ): $140 \mathrm{NaCl}$, $5 \mathrm{KCl}, 2 \mathrm{CaCl}_{2}, 1 \mathrm{MgCl}_{2}, 10$ HEPES, 10 Glucose and $\mathrm{pH} 7.4$ with $\mathrm{NaOH}$; the pipette solution contained (in $\mathrm{mM}$ ): $145 \mathrm{CsCl}, 1 \mathrm{MgCl}_{2}, 10$ EGTA, 4 TEA-Cl, 10 HEPES, 5 ATP- $\mathrm{Na}_{2}$ and $\mathrm{pH} 7.2$ with $\mathrm{CsOH}$. Patch pipettes were pulled to a tip resistance of 5-10 M $\Omega$ from a borosilicate glass capillary tube on a two-stage puller (PP83; Narishige, Tokyo, Japan). Voltage-clamp recording was obtained using an Axon-200B amplifier (Molecular Devices Corporation, Sunnyvale, USA). The series resistance was compensated by $50-70 \%$. Data were digitised at $200 \mathrm{kHz}$. To examine the activation properties, neurons were held at $-80 \mathrm{mV}$ and depolarised to potentials ranging from -80 to $60 \mathrm{mV}$ for $20 \mathrm{~ms}$ with $10 \mathrm{mV}$ stepping and $0.5 \mathrm{~Hz}$ frequency. To examine the inactivation properties, $\mathrm{Na}^{+}$currents were recorded at $-25 \mathrm{mV}$ after pre-pulse from -100 to $0 \mathrm{mV}$ for $40 \mathrm{~ms}$ with $10 \mathrm{mV}$ stepping.

To measure the amplitude and threshold of the spike, current-clamp recording was carried out in the above bath solution. The pipette solution contained (in $\mathrm{mM}$ ): $130 \mathrm{KCl}, 10 \mathrm{NaCl}, 1 \mathrm{MgCl}_{2}, 10$ EGTA, 10 HEPES, 10 glucose, 5 ATP- $\mathrm{Na}_{2}$ and $\mathrm{pH} 7.2$ with $\mathrm{KOH}$. The neurons were held around $-70 \mathrm{mV}$ by injecting a hyperpolarisation current, and the spike was elicited by a $500 \mathrm{pA}$ depolarising ramp current for $100 \mathrm{~ms}$. All experiments were conducted at room temperature.

Total RNA extraction, reverse transcription and real-time PCR

To determine the effects of IL- 6 on the expression of $\mathrm{Na}^{+}$channel proteins, the content of $\alpha_{1 \mathrm{~A}}$ subunit mRNA was measured using real-time PCR. For this experiment, to maximise the percentage of the neurons, the cells were cultured serum-free in Neurobasal-A medium (Invitrogen) with 2\% B-27. A selective inhibitor of DNA synthesis, arabinosylcytosine $\mathrm{C}(10 \mu \mathrm{M})$, was added to the medium at day 3 for $24 \mathrm{~h}$ to eliminate the glia cells, such as astrocytes.

Total RNA was extracted from cultures using TRIZOL (Invitrogen) according to the manufacturer's instructions. The purified RNA was reverse transcribed to cDNA with oligo dT-20 primers. Real-time PCR was performed using Mx3000p QPCR system (Stratagene Corporation, USA) with SYBR green fluorophore. A total reaction volume of $20 \mu \mathrm{l}$ contained $10 \mu \mathrm{l}$ SYBR Green PCR Master Mix (Applied Biosystems, NY, USA), 


\section{Li et al.}

$1 \mu \mathrm{l}$ cDNA template and $0.8 \mu \mathrm{l}$ forward/reverse primers (SCN1 $\alpha$ forward: 5'-GATGTTCTACGAGGTCTGG-3'; SCN1 $\alpha$ reverse: 5'-AGTTTGTTCGGTTGT GGT-3'0; GAPDH forward: 5'-ATCAAGAAGGTGGTGAA GCA-3'; GAPDH reverse: 5'-AAGGTG GAAGAA TGGGAGTTG-3'). The templates were amplified using the following PCR protocol: $95^{\circ} \mathrm{C}$ for $10 \mathrm{~min}$, 40 cycles of $95^{\circ} \mathrm{C}$ for $30 \mathrm{~s}$ and $60^{\circ} \mathrm{C}$ for $1 \mathrm{~min}$.

\section{Immunoblot analysis}

Membranes were purified by discontinuous sucrose gradient centrifugation. Briefly, whole-brain lysates in $0.32 \mathrm{M}$ sucrose $/ 5 \mathrm{Mm}$ Tris, $\mathrm{pH} 7.4$ were layered onto $1.2 \mathrm{M}$ sucrose $/ 5 \mathrm{mM}$ Tris, $\mathrm{pH} \quad 7.4$ and centrifuged at $100000 \mathrm{~g}$ for $30 \mathrm{~min}$. The protein fraction at the $0.8-1.2 \mathrm{M}$ sucrose interface was collected, diluted twofold with $0.8 \mathrm{M}$ sucrose $/ 5 \mathrm{mM}$ Tris, pH 7.4 and centrifuged at $20000 \mathrm{~g}$ for $20 \mathrm{~min}$. Pelleted membrane proteins were resuspended in one RIA buffer $(25 \mathrm{mM}$ Tris, $150 \mathrm{mM} \mathrm{NaCl}, 1 \mathrm{mM}$ EDTA, 2\% Triton $\mathrm{X}-100, \mathrm{pH} 7.4$ ) and centrifuged at $20000 \mathrm{~g}$ for $20 \mathrm{~min}$, and the supernatant containing the membrane proteins was collected for analysis. Complete Protease Inhibitor set (Roche, Basle, Switzerland) was included in all solutions. Membrane proteins $(100 \mathrm{mg})$ were fractionated by SDS-PAGE and immunoblotted using specific sodium channel antibodies: anti-Na V1.1 (Abcam; diluted 1:500).

Data analysis

Data were expressed as mean \pm SEM. Statistical analysis was performed using Origin software (Origin Lab Corporation, Northampton, USA) and SPSS 15.0 (SPSS Inc., USA). One-way ANOVA followed by LSD was used for comparison of the normative $\mathrm{Na}^{+}$currents amplitudes, current density $(\mathrm{pA} / \mathrm{pF})$, currents dose-dependent and timedependent, the thresholds and ampulitudes of spikes, qPCR data and protein expression level. Student's $t$-test was used for the comparison of activation curve and inactivation curve between two groups. For real-time PCR, the results were analysed with the Sequence Detector Software version 2.1 (Applied Biosystems). According to the comparative threshold cycle (CT) method, the relative gene expression was calculated by the formula $2^{-\left(\Delta \Delta \mathrm{C}_{\mathrm{T}}\right)}$.

\section{Results}

Dose-dependence of the inhibition of IL-6 on $\mathrm{Na}^{+}$currents

The spinal cord cultures were treated with IL-6 at $0.1,1$ and $10 \mathrm{ng} / \mathrm{ml}$ for $24 \mathrm{~h}$ before the wholecell voltage-gated $\mathrm{Na}^{+}$currents were recorded.
An inward current with fast activation and inactivation was elicited by depolarisation from $-80 \mathrm{mV}$ of the holding potential and recorded at $200 \mathrm{kHz}$ of the sampling frequency (Fig. 1a). To obviate the difference in $\mathrm{Na}^{+}$currents caused by the various sizes of the neurons in our recording, the current density was calculated by the peak current divided by membrane capacitance that was obtained in the lock-in simulative protocol of the Axon-200B amplifier. The voltage-gated $\mathrm{Na}^{+}$currents were significantly inhibited at the most activated potentials by $1 \mathrm{ng} / \mathrm{ml}$ or higher $(10 \mathrm{ng} / \mathrm{ml})$ of IL-6, but not by $0.1 \mathrm{ng} / \mathrm{ml}$ of IL-6 (Fig. 1b). The peak currents, up to $-10 \mathrm{mV}$, were plotted to the dosages of IL- 6 and the results showed that the inhibition by IL-6 appeared to be dose-dependent. The $\mathrm{Na}^{+}$ currents were suppressed by $\sim 6,39$ and $46 \%$ by $0.1,1$ and $10 \mathrm{ng} / \mathrm{ml}$ of IL-6, respectively (Fig. 1c). IL-6 receptor antibody was used to test whether the IL-6 inhibition is IL-6R-dependent, and the result showed that IL-6ra abolished the inhibitory effects of IL- 6 on $\mathrm{Na}+$ currents and did not alter the currents when used alone (Fig. 1d). Anti-gp130 antibody at $1 \mu \mathrm{g} / \mathrm{ml}$ was used to test whether the Janus kinase/signal transducer and activator of transcription (JAK/STAT) signal transduction pathway contribute to IL-6 inhibition and subsequent result showed that anti-gp130 antibody abolished the inhibitory effects of IL-6 on $\mathrm{Na}^{+}$ currents (Fig. 1e).

Time-dependence of IL-6 inhibition on $\mathrm{Na}^{+}$currents

To examine whether the effects of IL- 6 on $\mathrm{Na}^{+}$ currents are time-dependent, $10 \mathrm{ng} / \mathrm{ml}$ of IL- 6 was chosen in the further experiments. The neurons were treated with IL- 6 at $10 \mathrm{ng} / \mathrm{ml}$ for $4,8,24$ and $48 \mathrm{~h}$, respectively, and results showed that IL- 6 inhibited the voltage-gated $\mathrm{Na}^{+}$current significantly at $24 \mathrm{~h}$ treatment (Fig. 2a). The reduction of the currents induced by IL- 6 at, 4, 8, 24 and $48 \mathrm{~h}$ were $28 \%$, $42 \%, 51 \%$ and $22 \%$, respectively (Fig. $2 b$ ).

Effects of IL-6 on the activation and inactivation of $\mathrm{Na}^{+}$channels

To identify other possible effects of IL-6 on the voltage-gated $\mathrm{Na}^{+}$channels, the voltage-dependent activation and inactivation properties of the $\mathrm{Na}^{+}$ channels at each dose and period of IL- 6 treatments were analysed and compared. For the activation, the conductance at each voltage was calculated by the peak current and driving potential and then normalised by the maximal conductance. The normative conductance was plotted to the depolarised voltage, and the conductance-voltage 
(a)

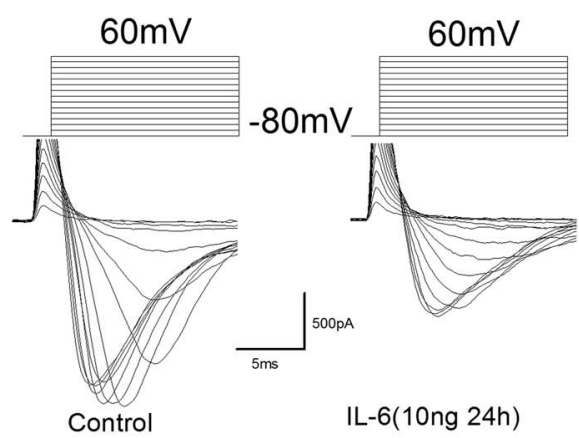

(c)

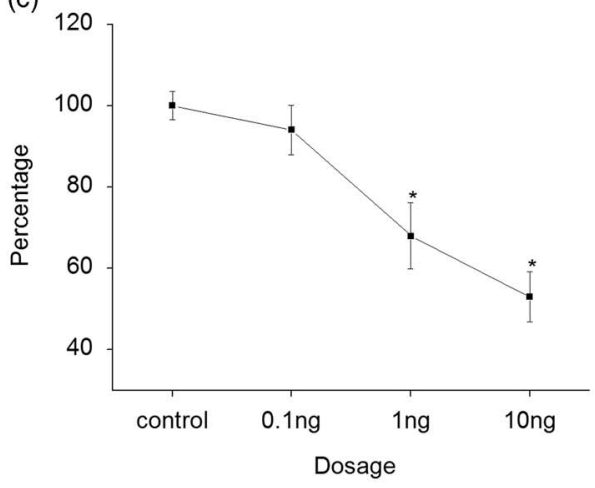

(b)

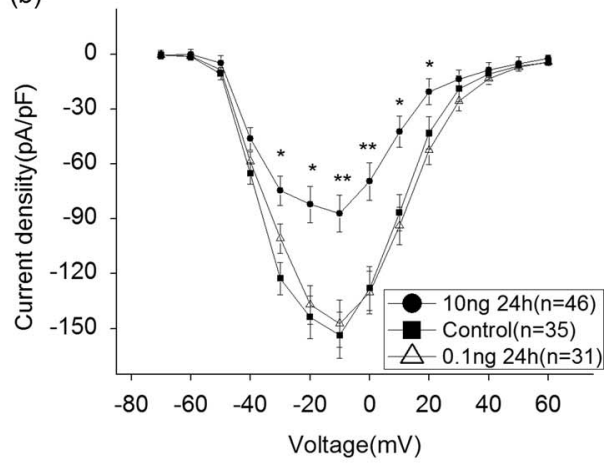

(d)

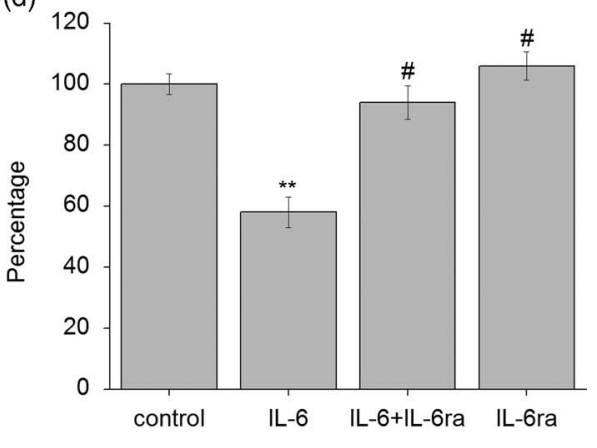

(e)

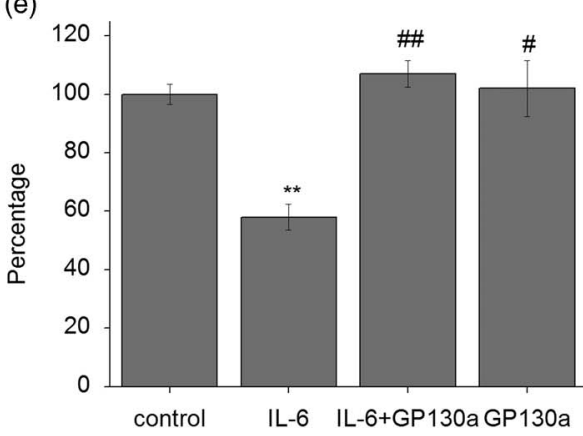

Fig. 1. The effects of IL-6 on voltage-gated $\mathrm{Na}^{+}$currents were dose-dependent and through its receptor and gp130 in the cultured spinal cord neurons of rats. (a) A typical recording curve of whole-cell $\mathrm{Na}^{+}$currents from -80 to $60 \mathrm{mV}$ in the control and IL-6-treated $(10 \mathrm{ng} / \mathrm{ml}, 24 \mathrm{~h})$ neurons. (b) The current density-voltage relationship in 0.1 and $10 \mathrm{ng} / \mathrm{ml}(24 \mathrm{~h})$ of IL-6-treated groups. ${ }^{*} p<0.05$ and ${ }^{*} p<0.01$ as compared with control (one-way ANOVA followed by LSD test). (c) The dose-dependency of IL-6 effects on $\mathrm{Na}^{+}$currents ranged from 0.1 to $10 \mathrm{ng} / \mathrm{ml}$. The current data were normalised by control respectively and expressed as percentage of control group. (d) The normative $\mathrm{Na}^{+}$currents amplitudes at $-10 \mathrm{mV}$ in control, IL-6 only, IL-6+IL-6ra and IL-6ra only groups. (e) The normative $\mathrm{Na}^{+}$currents amplitudes at $-10 \mathrm{mV}$ in control, IL-6 only, IL-6+anti-gp130 antibody; anti-gp130 antibody only ${ }^{*} p<0.05$ and ${ }^{* *} p<0.01$ as compared with control; ${ }^{*} p<0.05$ and ${ }^{\# \#} p<0.01$ as compared with IL-6 group (one-way ANOVA followed by LSD test).

curves were fitted using the Boltzmann equation (Fig. 3a). For the inactivation analysis, the peak currents at $-25 \mathrm{mV}$ of the test voltage were normalised by the maximal current (Fig. 3b). The normative currents were plotted to the prepulse voltage, and the current-voltage curves were also fitted using the Boltzmann equation (Fig. 3b). Neither the activation nor inactivation properties were affected by IL- 6 at any doses or administered time used in this study - even those that significantly reduced the whole-cell $\mathrm{Na}^{+}$currents (e.g. $10 \mathrm{ng} / \mathrm{ml}$ for $24 \mathrm{~h}$; Fig. $3 a$ and $b$ ). The entire parameters (i.e. $V_{1 / 2}$ and slope factor) of voltage-dependent activation and inactivation were summarised in Tables 1 and 2 .

Using real-time PCR, we estimated $\alpha 1 \mathrm{~A}(\mathrm{SCN} 1 \alpha)$ subunit mRNA in the neurons and found that the $\alpha 1 \mathrm{~A}$ subunit expression was significantly inhibited by IL- 6 at $10 \mathrm{ng} / \mathrm{ml}$ for $2 \mathrm{~h}$. This expression 


\section{Li et al.}

(a)

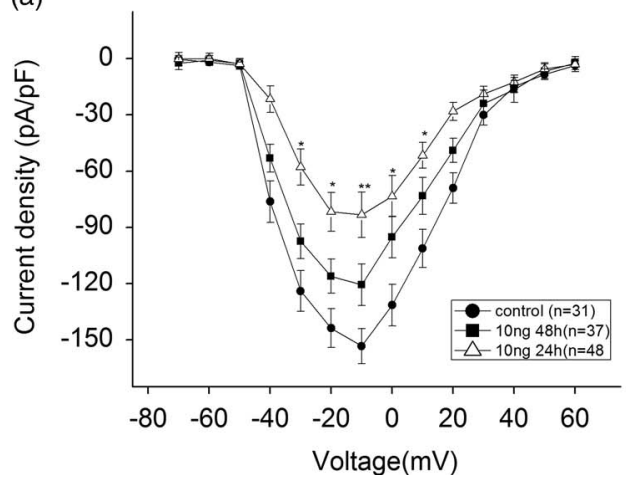

(b)

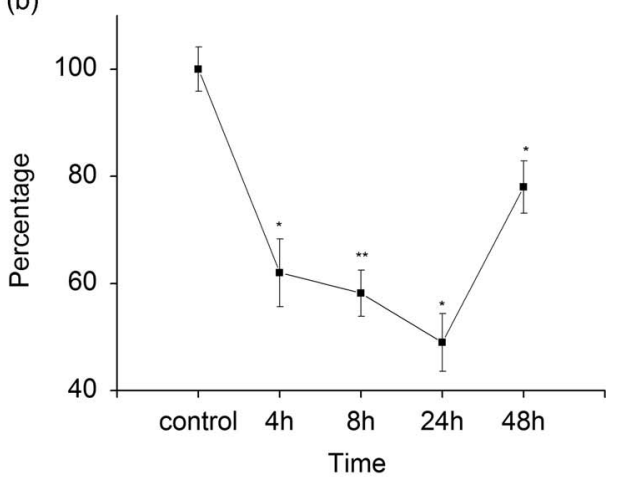

Fig. 2. The effects of IL-6 on voltage-gated $\mathrm{Na}^{+}$currents were time-dependent in the cultured spinal cord neurons of rat. (a) The current density-voltage relationship in $10 \mathrm{ng} / \mathrm{ml}$ of IL-6-treated for 24 and $48 \mathrm{~h}$, respectively. ${ }^{*} p<0.05$ and ${ }^{* *} p<0.01$ as compared with control (one-way ANOVA followed by LSD test). (b) The time-dependency of IL-6 (10 ng/ml) effects on Na ${ }^{+}$currents ranged from 4 to $48 \mathrm{~h}$. The current data were normalised by control respectively and expressed as percentage of control group. ${ }^{*} p<0.05$ and ${ }^{* *} p<0.01$ as compared with control (one-way ANOVA followed by LSD test).

(a)

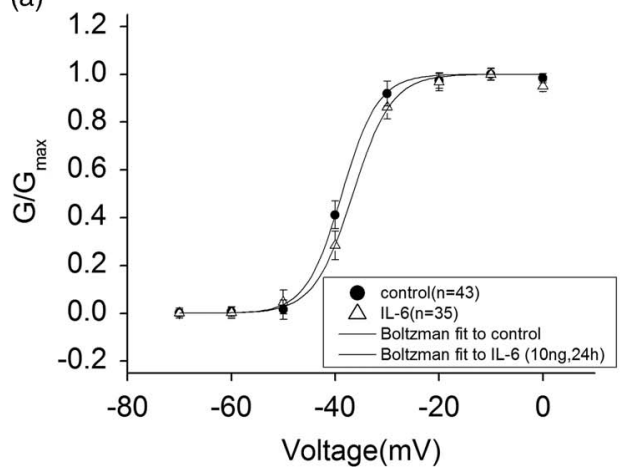

(b)

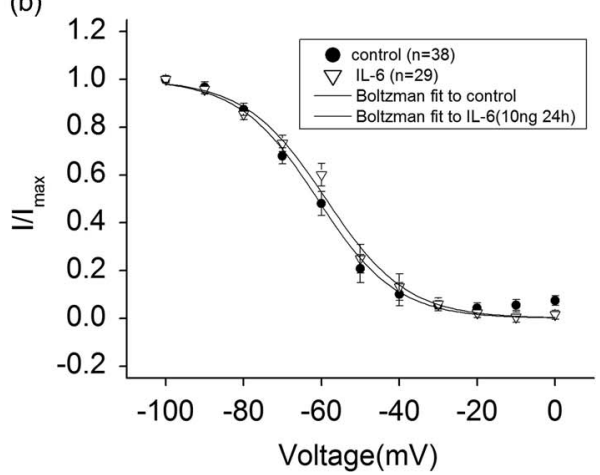

Fig. 3. The effects of IL-6 on electrophysiological characteristics. (a) Voltage-dependent activation curves (Boltzmann equation and fitting parameters) in $10 \mathrm{ng} / \mathrm{ml}$ treated for $24 \mathrm{~h}$ and control groups. (b) A typical curve for the analysis of inactivation properties (insert) and voltage-dependent inactivation curves (Boltzmann equation and fitting parameters) in $10 \mathrm{ng} / \mathrm{ml}$ treating for $24 \mathrm{~h}$ and control groups. ${ }^{*} p<0.05$ as compared with control (Student's $t$-test).

Table 1. Parameters of voltage-dependent activation

\begin{tabular}{|c|c|c|c|c|c|c|c|}
\hline & \multirow[b]{2}{*}{ Control } & \multirow{2}{*}{$\frac{0.1 \mathrm{ng} / \mathrm{ml}}{24 \mathrm{~h}}$} & \multirow{2}{*}{$\frac{1 \mathrm{ng} / \mathrm{ml}}{24 \mathrm{~h}}$} & \multicolumn{4}{|c|}{$10 \mathrm{ng} / \mathrm{ml}$} \\
\hline & & & & $4 \mathrm{~h}$ & $8 \mathrm{~h}$ & $24 \mathrm{~h}$ & $48 \mathrm{~h}$ \\
\hline $\mathrm{V}_{1 / 2}(\mathrm{mV})$ & $-44.8 \pm 0.8$ & $-49.8 \pm 1.4$ & $-39.5 \pm 1.3$ & $-42.1 \pm 0.6$ & $-46.9 \pm 0.9$ & $-37.8 \pm 1.2$ & $-46.9 \pm 1.6$ \\
\hline Slope factor & $3.4 \pm 0.4$ & $5.5 \pm 0.7$ & $3.6 \pm 0.3$ & $4.3 \pm 0.8$ & $5.2 \pm 0.9$ & $4.6 \pm 0.7$ & $4.3 \pm 0.4$ \\
\hline
\end{tabular}

Table 2. Parameters of voltage-dependent inactivation

\begin{tabular}{|c|c|c|c|c|c|c|c|}
\hline & \multirow[b]{2}{*}{ Control } & \multirow{2}{*}{$\frac{0.1 \mathrm{ng} / \mathrm{ml}}{24 \mathrm{~h}}$} & \multirow{2}{*}{$\frac{1 \mathrm{ng} / \mathrm{ml}}{24 \mathrm{~h}}$} & \multicolumn{4}{|c|}{$10 \mathrm{ng} / \mathrm{ml}$} \\
\hline & & & & $4 \mathrm{~h}$ & $8 \mathrm{~h}$ & $24 \mathrm{~h}$ & $48 \mathrm{~h}$ \\
\hline $\mathrm{V}_{1 / 2}(\mathrm{mV})$ & $-60.2 \pm 1.1$ & $-53.2 \pm 1.6$ & $-56.9 \pm 0.9$ & $-48.3 \pm 1.5$ & $-51.7 \pm 2.5$ & $-57.1 \pm 1.4$ & $-52.4 \pm 1.8$ \\
\hline Slope factor & $10.4 \pm 0.6$ & $13.0 \pm 1.1$ & $8.2 \pm 0.3$ & $12.6 \pm 1.3$ & $8.8 \pm 0.7$ & $11.5 \pm 0.6$ & $9.3 \pm 1.4$ \\
\hline
\end{tabular}

inhibition was transient, peaked at $2 \mathrm{~h}$ and recovered at $4 \mathrm{~h}$ and thereafter (Fig. 4a). The result of the immunoblot analysis showed that $\mathrm{SCN} 1 \alpha$ subunit protein level was suppressed steadily by IL-6 $(10 \mathrm{ng} / \mathrm{ml})$ at 4,8 and $24 \mathrm{~h}$ (Fig. $4 \mathrm{~b}$ and c). Together these results suggest that IL-6 inhibits the 
(b)
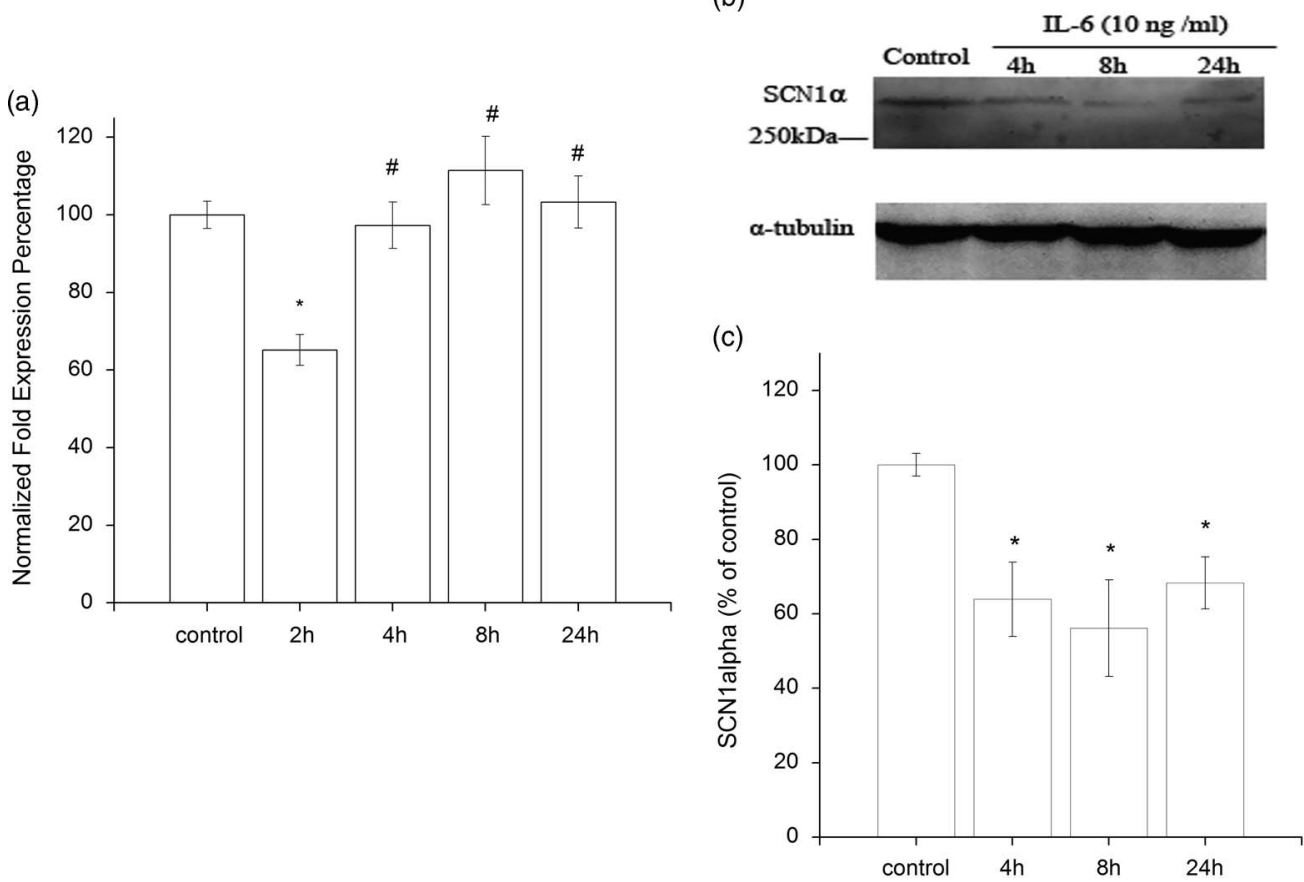

Fig. 4. The expression of $\alpha_{1 \mathrm{~A}}$ subunit in mRNA level and protein level with control. (a) The expression of $\alpha_{1 \mathrm{~A}}$ subunit was significantly reduced by IL-6 $(10 \mathrm{ng} / \mathrm{ml})$ treatment at $2 \mathrm{~h}$, but not 4,8 or $24 \mathrm{~h}$. ${ }^{*} p<0.05$ as compared with control; ${ }^{\#} p<0.05$ and $\# p<0.01$ as compared with $2 \mathrm{~h}$ group (one-way ANOVA followed by LSD test). (b) The protein expression of the SCN1 $\alpha$ subunit was significantly downregulated by IL-6 $(10 \mathrm{ng} / \mathrm{ml})$ at 4,8 and $24 \mathrm{~h}$. (c) The data are from three separate experiments. ${ }^{*} p<0.05$, compared with control (one-way ANOVA followed by LSD test).

$\mathrm{Na}^{+}$currents through not changing the essential characteristics of the voltage-gated $\mathrm{Na}+$ channels in the neurons, but reducing the amount of channels in the plasma membrane.

\section{Effects of IL-6 on amplitude and threshold of the spike}

Voltage-gated $\mathrm{Na}^{+}$channels are essential in achieving the rising phase and overshoot of the AP. To probe the IL-6 effects on the AP, the spikes were recorded in a current-clamp configuration (Fig. 5). The threshold of the spike was not affected by IL-6 (Fig. 5c). On the other hand, the peak of the spike was lowered significantly by $10 \mathrm{ng} / \mathrm{ml}$ of IL-6 for $24 \mathrm{~h}$, but not changed at 1 or $0.1 \mathrm{ng} / \mathrm{ml} \mathrm{IL-6} \mathrm{(Fig.} \mathrm{5d).} \mathrm{These} \mathrm{results}$ agree well with the data from the current density recording and suggest that IL-6 reduces the amplitude of the AP by inhibition on the voltage-gated $\mathrm{Na}^{+}$ channels in the cortical neurons.

\section{Discussion}

IL-6 plays an important role in various pathophysiological conditions of the CNS via its receptor-mediated intracellular signal cascades (23). Some studies have reported on the relationship between IL-6 and ion channels in the neurons, including acute effects on L-type calcium channel of the cultured cerebellar granule neurons (24), chronic effects on the mean amplitude of the calcium signal in response to glutamate receptor agonists in the cultured cerebellar Purkinje neurons (23). This study newly found that IL-6 can inhibit the voltage-gated $\mathrm{Na}^{+}$currents, but not voltage-dependent activation/ inactivation (e.g. AP) in the cultured spinal cord neurons. It is known that the reduction of $\mathrm{Na}^{+}$ currents declines energy consumption that is used for maintaining the $\mathrm{Na}^{+}$gradient across the plasma membrane in the injured neurons. Thereby, IL-6 suppressed $\mathrm{Na}^{+}$currents in the spinal cord neurons may promote neuronal survival in injuries and diseases of the CNS. On the other hand, an extensive amount of literature suggests that IL-6 has a negative effect on neuronal survival and neuroprotection in an in vivo model of CNS disease (25-27). Both real-time PCR and immunoblot results revealed the decrease of the channel gene expression, and the antibody of IL-6 receptor abolished this inhibition, indicating that IL-6 functions through its receptor-mediated mechanism.

The characteristics of IL-6-induced changes in the physiological properties of the spinal cord neurons were dependent on the dose of IL-6 and the duration of exposure. However, the relationship between the 
Li et al.

(a)
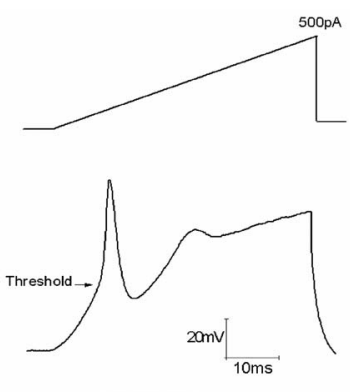

Control

(c)

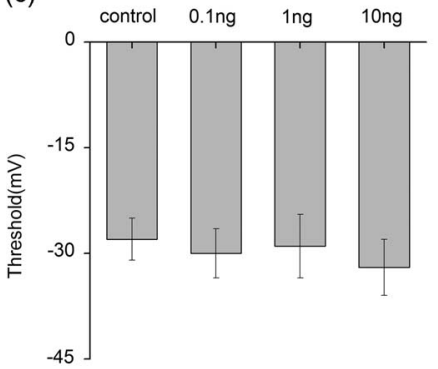

(b)
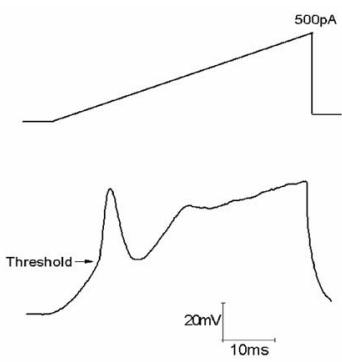

IL-6 (10ng 24h)

(d)

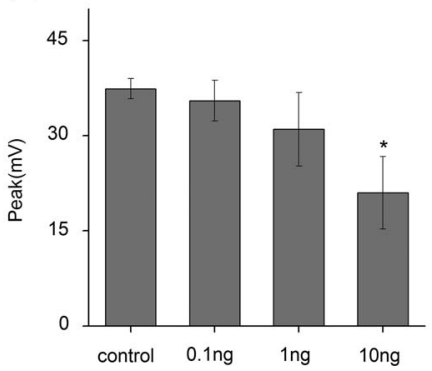

Fig. 5. The effects of IL-6 on spike. (a and b) Typical curves of spike elicited by a ramp depolarised current in control group (a) and IL-6 (10 ng for 24h) treated group (b). (c and d) The thresholds (c) and amplitudes (d) of spike in control $(n=31), 0.1(n=26), 1$ $(n=21)$ and $10(n=18) \mathrm{ng} / \mathrm{ml} \mathrm{IL-6-treated} \mathrm{groups.}{ }^{*} p<0.05$ as compared with control (one-way ANOVA followed by LSD test).

dose/duration of IL-6 and the effect was not always straightforward. For example, $0.1-10 \mathrm{ng} / \mathrm{ml}$ IL-6 exposure for $24 \mathrm{~h}$ resulted in dose-dependent reductions in $\mathrm{Na}^{+}$currents, whereas at $10 \mathrm{ng} / \mathrm{ml}$ of IL-6, $\mathrm{Na}^{+}$currents were decreased significantly at 4, 8 and $24 \mathrm{~h}$. The currents returned nearly to the control level after $48 \mathrm{~h}$. Similar to the voltage data, the mRNA level of $\alpha 1 \mathrm{~A}$ subunit was reduced at $2 \mathrm{~h}$ but recovered sooner. These results implicate that IL-6 regulates the $\mathrm{Na}^{+}$channel activity by reducing its expression. The level of mRNA returns to normal at $4 \mathrm{~h}$, whereas currents were reinstated at $48 \mathrm{~h}$, which indicates that the switch-on of $\mathrm{Na}^{+}$channel gene expression is an immediate event with a narrow window, but the recovery of currents may depend on the half-life of the proteins. Further approach is warranted to clarify this question.

It has been reported that IL- 6 acts on the target cells and promotes dimerisation of gp130, a signaltransducing subunit coupled with the IL-6 receptor $(23,28)$, which is confirmed in our experiments (Fig. 1b and c). The spinal cord neurons express IL-6 receptors and gp130 signal protein $(29,30)$. In this study, anti-gp130 antibody blocked the inhibitory activity of IL-6 on glutamate-induced intracellular $\mathrm{Ca}^{2+}$ overload, indicating that the IL-6 receptor is involved in the neuroprotective effect of IL-6. Therefore, we deduce that the IL-6-induced inhibition of voltage-gated sodium activities is achieved through a receptor-mediated mechanism.
A spike was recorded using current-clamp technique in our experimental conditions. The threshold of the spike was stable in various experimental groups, in agreement with the stability of the voltage-dependent activation of the $\mathrm{Na}^{+}$currents. The current-clamp recording data showed that IL-6 decreased the AP amplitude of neurons, in which $\mathrm{Na}^{+}$currents were also inhibited. A large number of studies have indicated that IL- 6 can reduce neuronal death via a reduction of $\mathrm{Ca}^{2+}$ entry into the neurons $(23,31)$. The reduction of AP amplitude may indirectly decrease the $\mathrm{Ca}^{2+}$ influx through voltage-gated $\mathrm{Ca}^{2+}$ channels during the spike, and thus protect the neurons from injury induced by $\mathrm{Ca}^{2+}$ overload. Excitotoxicity resulting from the excessive release of excitatory transmitters is involved in many CNS diseases and injuries $(32,33)$. The reduction of AP amplitude revealed that IL- 6 may decrease the release of neurotransmitters from the presynaptic terminal.

In conclusion, we demonstrated that IL-6 inhibits the voltage-gated $\mathrm{Na}^{+}$currents in a time- and dosedependent manner through IL-6 receptor and gp130, but does not affect the voltage-dependent activation and inactivation in the spinal cord neurons. These results suggest that IL- 6 may regulate the properties of the AP in the neurons via its effects on $\mathrm{Na}^{+}$channels. The potential neuroprotection of IL-6 may be ascribed to its inhibitory effect on $\mathrm{Na}^{+}$currents, reducing energy consumption in the injured neurons or the release of excitatory transmitters in excitotoxicity. 


\section{Acknowledgement}

This work was supported by the National Natural Science Foundation of China (No. 30800572).

\section{References}

1. Gadient RA, Otten UH. Interleukin-6 (IL-6) - a moleculen with both beneficial and destructive potentials. Prog Neurobiol 1997;52:379-390.

2. Hopkins SJ, Rothwell NJ. Cytokines and the nervous system I: expression and recognition. Trends Neurosci 1995; 18:83-88.

3. VAN WAGONER NJ, BENVENISTE EN. Interleukin-6 expression and regulation in astrocytes. J Neuroimmunol 1999;100: 124-139.

4. Kaplin AI, Deshrande DM, Scott E et al. IL-6 induces regionally selective spinal cord injury in patients with the neuroinflammatory disorder transverse myelitis. J Clin Invest 2005; 115:2731-2741.

5. Brisby H, Olmarker K, Larsson K et al. Proinflammatory cytokines in cerebrospinal fluid and serum in patients with disc herniation and sciatica. Eur Spine J 2002;11:62-66.

6. КАNЕмото M. Immunohistochemical study of matrix metalloproteinase-3 and tissue inhibitor of metalloproteinase1 in human intervertebral disk. Spine 1996;21:1-8.

7. Tuna M, Polat S, EnNan T et al. Effect of anti-rat interleukin6 antibody after spinal cord injury in the rat: inducible nitric oxide synthase expression, sodium-and potassiumactivated, magnesium-dependent adenosine-5'-triphosphatase and superoxide dismutase activation, and ultrastmetural changes. J Neurosurg 2001;96:64-73.

8. Neuhuber B, Timothy Himes B, Shumsky JS, Gallo G, FISCHER I. Axon growth and recovery of function supported by human bone marrow stromal cells in the injured spinal cord exhibit donor variations. Brain Res 2005;1035:73-85.

9. Sallmann S, Juttler E, Prinz $\mathrm{S}$ et al. Induction of interleukin- 6 by depolarization of neurons. J Neurosci 2000;20:8637-8642.

10. Jones TB, McDaniel EE, Popovich PG. Inflammatorymediated injury and repair in the traumatically injured spinal cord. Curr Pharm Des 2005;11:1223-1236.

11. Carlson NG, Wieqqel WA, Chen J, Bacchi A, Rogers SW, GAHRING LC. Inflammatory cytokines IL-1alpha, IL-1 beta, IL-6, and TNF-alpha impart neuroprotection to an excitotoxin through distinct pathways. J Immunol 1999;163:3963-3968.

12. Liu Z, QIU YH, Li B et al. Neuroprotection of interleukin-6 against NMDA-induced apoptosis and its signaltransduction mechanisms. Neurotox Res 2011;11:484-495.

13. Pizzi M, Sarnico I, Boroni F, Benarese M, Dreano M, Garotta G. Prevention of neuron and oligodendrocyte degeneration by interleukin-6 (IL-6) and IL-6 receptor/IL-6 fusion protein in organotypic hippocampal slices. Mol Cell Neurosci 2004;25:301-311.

14. WANG XQ, PENG YP, Lu JH et al. Neuro-protection of interleukin-6 against NMDA attack and its signaltransduction by JAK and MAPK. Neurosci Lett 2009; 450: $122-126$.

15. Hodgkin AL, HuXley AF. A quantitative description of membrane current and its application to induction and excitation in nerve. J Physiol 1952;117:500-544.
16. Hille B. Ion Channels of Excitable Membranes. Sunderland, MA: Sinauer Associates Inc, 2001.

17. Zноu C, Qı $\mathrm{C}$, Zнао $\mathrm{J}$ et al. Interleukin-1 $\beta$ inhibits voltage-gated sodium currents in a time- and dose-dependent manner in cortical neurons. Neurochem Res 2001;31: $1116-1123$.

18. Goldfarb M, Schoorlemmer J, Williams A et al. Fibroblast growth factor homologous factors control neuronal excitability through modulation of voltage-gated sodium channels. Neuron 2007;55:449-463.

19. Rush AM, Dib-Haju SD, Liu S, Cummins TR, Black JA, WAXMAN SG. A single sodium channel mutation produces hyper-or hypoexcitability in different types of neurons. Proc Natl Acad Sci 2006;103:8245-8250.

20. HAINS BC, SAAB CY, KLeIN JP et al. Altered sodium channel expression in second-order spinal sensory neurons contributes to pain after peripheral nerve injury. J Neurosci 2004;23: 4832-4839.

21. Momin A, Wood JN. Sensory neuron voltage-gated sodium channels as analgesic drug targets. Curr Opin Neurol 2008; 18:383-388.

22. Deloulme JC, Baudier J, Sensenbrenner M. Establishment of pure neuronal cultures from fetal rat spinal cord and proliferation of the neuronal precursor cells in the presence of fibroblast growth factor. J Neurosci Res 1991;29:499-509.

23. Nelson TE, Ur CL, Gruol DL. Chronic interleukin-6 exposure alters electrophysiological properties and calcium signaling in developing cerebellar purkinje neurons in culture. J Neurophysiol 2002;88:475-486.

24. MA SH, Li B, HuANG HW et al. Interleukin-6 inhibits L-type calcium channel activity of cultured cerebellar granule neurons. J Physiol Sci 2012;62:385-392.

25. Spooren A, Kolmus K, Laureys G et al. Interleukin-6, a mental cytokine. J Brain Res Rev 2011;67:157-183.

26. Allan SM, Rothwell NJ. Inflammation in central nervous system injury. Phil Trans R Soc Lond B Biol Sci 2003;358:1669-1677.

27. Allan SM, Rothwell NJ. Cytokines and acute neurodegeneration. Nat Rev Neurosci 2001;2:734-744.

28. Peng YP, Qiu YH, Lu JH, WANG JJ. Interleukin-6 protects cultured cerebellar granule neurons against glutamate-induced neurotoxicity. Neurosci Lett 2005;374: 192-196.

29. YANG P, Wen H, Ou S et al. IL-6 promotes regeneration and functional recovery after cortical spinal tract injury by reactivating intrinsic growth program of neurons and enhancing synapse formation. Exp Neurol 2012;236: 19-27.

30. KANG MK. Kang SKInterleukin-6 induces proliferation in adult spinal cord-derived neural progenitors via the JAK2/ STAT3 pathway with EGF-induced MAPK phosphorylation. Cell Prolif 2008;41:377-392.

31. Georgene W, Anthony N, J Philip M et al. Serum IL-6: a candidate biomarker for intracranial pressure elevation following isolated traumatic brain injury. $\mathrm{J}$ Neuroinflammation 2010;7:7-19.

32. Jabaudon D, Scanziani M, GaÄhwiler BH, Gerber U. Acute decrease in net glutamate uptake during energy deprivation. Proc Natl Acad Sci 2000;97:5610-5615.

33. Nishizawa Y. Glutamate release and neuronal damage in ischemia. Life Sci 2001;69:369-381. 